\title{
Evaluation of Potentials for Peace Sustainability in the Post- Amnesty Niger Delta, Nigeria
}

\author{
Osah Goodnews $\mathrm{PhD}$ and Alao, David Oladimeji PhD \\ Department of Political Science and Public Administration, Babcock University, Nigeria
}

\begin{abstract}
The Niger Delta areas, Nigeria, through rich in natural resources had witnessed several decades of conflict on account of systematic degradation of the region. Cosmetic measures adopted by previous government achieved little or no result until relative peace was accomplished on implementation of amnesty programme by the federal government in 2009. This paper assessed the prospects for achieving sustainable peace to prevent a relapse of armed conflict. The paper was descriptive and relied on secondary data sources. The paper found that the disarmament programme had achieved relative success as not all the militant groups keyed into the programme. In addition the coverage of the rehabilitation programme was positively skewed in favour of the militants to the exclusion of the generality of the citizens while such exclusion may portend danger for the future. Furthermore, the amnesty programme was anchored on militants and notable personalities rather than institutionally based while the infrastructural development could still be improved upon to serve as solid foundation for speedy development. The study therefore concluded that sustainable peace is a possibility with sincerity of purpose by the stakeholders. The study recommended that the stakeholders adopt inclusive approach to correct the identified deficiencies.
\end{abstract}

Key words: Conflict, Militancy, Amnesty, Disarmament, Peace Sustainability, Niger Delta

\section{Introduction}

The oil rich region of the Niger Delta is inhabited by numerous ethnic nationalities that are very heterogeneous, with over 40 ethnic groups who speak more than 250 mutually unintelligible languages and dialects Ekpo (2004). Ethnic cleavages are intense but the people are bound together by a sense of grievance about the despoliation of their environment and a long battle for self determination and resource control (Ako, 2011; Francis, LaPin \& Rossiaco, 2011; Ibaba, 2011; Osaghae, 2011, Ikelegbe 2004). The huge income from crude oil and gas from the region which accounts for about $80 \%$ of government's revenue is believed not to have sufficient impact on the lives of the people in the area. Therefore, it is often argued that the wealth of the region is not significantly felt or ploughed back to the region (Ikelegbe, 2005b; Imobighe, 2004). While the wealth has not largely improved the lives of the people, effect of oil exploration, exploitation and transportation within the environment is very devastating, coupled with the many years of neglect by successive governments. The negative response to region's frustrations, have resulted into widespread agitations (Osaghae, 2011; Ikelegbe, 2010).

Conceptualizing the Niger Delta region has elicited several viewpoints from scholars, but the two major definitions of the region are its geographical expanse and its ecological features. Some scholars including Oku (2003); Fubara (2002); Isoun (2001) speak of the region based on its geographical and ethnic make-up comprising of ethnic minorities with a rich and closely related cultural heritage. The Niger-Delta region has a total population of about 30 million people living about in 1600 communities that spread over about 70,000 square kilometers and the fourth largest ethnic group in Nigeria (Alao, 2010; National Population Commission, 2006). Since 1999, when President Olusegun Obasanjo assumed power at the Federal level, nine states namely: Abia, Akwa Ibom, Bayelsa, Cross River, Delta, Edo, Imo, Ondo, and Rivers, which are oil producing have become identified with the Niger Delta (NDDC, 2000). This debate over the definition of the region has led to several terminologies such as the 'Oil Rivers Protectorate', 'natural Niger Delta', 'core Niger Delta', 'political Niger Delta', 'South-South geo-political zone' and 'oil producing areas' to describe the Niger Delta (Akpabio \& Akpan, 2010; Nwachukwu, 2008; Azaiki, 2007; Oku, 2003; Isoun, 2001). The perceived or real neglect of the region since the discovery of crude oil in 1956 led to Niger Delta crisis while the paper is set to examine the potentials for enduring post amnesty peace deal.

\section{Theoretical Framework}

The peculiarity of the Niger Delta crisis requires the adoption of appropriate framework to provide sufficient base for "war to peace program". The system theory as propounded by Easton (1965) provided an understanding of the relationship that exist among various parts of the system that can explain their functionality whether it will be harmonious or not. Almond's structural functionalism is an advanced form of system model 
but they are not sufficiently suggestive of how sustainable peace could be achieved. Same is true of Dollard, Dobb, Miller, Mower, and Seers (1939) frustration aggression theory and the derivatives that provided insight into causative factor. They paper among other prevailing theories adopt Galtung (2000) Transcend theory. It was propounded by Galtung with focus not only on conflict but its transformation to peace by demonstrating what wrong, the flow and measures to curb it. It is suitable for this paper as the emphasis is on war to peace programme. It illustrated conflict triangle, conflict pillars, and violence triangle and post conflict process towards enduring peace. Though criticized particularly by Western scholars including kay (2009), Bawer (2007) and Boulding (1977) among others as intellectually incoherent and that "ideology always trump s objectivity and pragmatism" others such as Morris, Hoffman and Peachey (2009) Doyle and Sambanis (2006) among others note that the critics underestimated the development of detailed interdisciplinary and theoretical and methodological development in the field while his work has influenced the programme of many international bodies like the World bank and United Nations Organization. What went wrong with Niger Delta crisis has been over flogged but no sufficient insight on how to achieve sustainable peace that informed the adoption of this theory.

\section{Evolution Of The Niger Delta Crisis}

Scholars such as Anifowose (2011); Okai (2008); Ikelegbe (2001); Osaghae (1995); Tamuno (1972) have placed the conflict in the Niger Delta region on a context of resistance politics. This dates back to the period of the slave trade in the $16^{\text {th }}$ century when productive youths were transported to the European plantations to work for the slave masters and develop their economies. Alao (2010) notes that by the mid- 1900, the Niger- Delta city states became the leading African exporter of palm oil following the stoppage of slave trade as this further entrenched European involvement in and encroachment, not only upon African politics but economic nerves region. The European buyers fixed the price of the product and did not allow indigenous producer to engage in direct exportation of their products. The attempt by the Efik of Calabar in 1851 to ship palm oil directly to Europe by chartered ship thus by-passing the English middle-men and raising profit by $100 \%$ was blocked by the British Naval support according to Boahen (1981). This could be regarded as one of the earliest steps by the European traders to frustrate the development of the indigenous states and business. This led to the Europeans onslaught on King William Dappa Pepple of Bonny, King Jaja of Opobo, Prince Nana of Itsekiri, King Ibanichuka of Okirika, Overnarame, and King Koko of Brass who rose against such wicked practices.

By the 1950s, the Ijaws had mobilized themselves and decried the developmental deficiencies from the colonial period. This was so persuasive that Sir Henry Willink of the Colonial Office in London came to head a Commission appointed to inquire into the fears of the minorities and the means of allaying them in 1958 (The Willink Commission Report, 1958). The situation persisted till oil was struck in Oloibiri in 1956 while commercial exploitation began in 1958 .

The hope of the people for reprieve in the 1960s and 1970s met with a brick wall as the fiscal arrangements which existed during the First Republic based on 50 percent derivation formula was abolished by the military regime of General Yakubu Gowon. General Gowon had argued that he needed more money to execute the Nigerian civil war against the secessionist Biafra Republic. However, at the end of the war in 1970, the fiscal arrangement was not reverted instead many obnoxious policies and legislations were enacted to alienate the people of the region from the management of the oil resources (Nna-Ntete, 2001; Obi, 2000; Sogwe, 1997). The situation culminated into violent attempts to forcibly assert regional autonomy for the Niger Delta region and by February 23, 1966, Isaac Jasper Adaka Boro, an ethnic minority Ijaw militant leader and his 59 man Niger Delta Volunteer Force (NDVF) engaged the Nigerian state in a Twelve Day Revolution in attempt to secede and establish a Niger Delta Republic with an eleven-point declaration of independence (Boro, 1982). Boro thought that the resources from the region would be utilized for the well being of the people with their destiny in their own hands (Akinwale, 2010; Osaghae, 2008).

In addition, the Ijaw Youth Council's Kaima declaration of 1998, among other things, aimed at ceasing to recognize all undemocratic decrees that rob the region of the right to ownership and control of their resources. Oil companies were expected to end gas flaring and withdraw from Ijaw land before January 1999 as reported by Human Right Watch (2003). On account of the peaceful protest by Ijaw Youths in Yenogoa, the Abdulsalami Abubakar-led administration dispatched several warships and soldiers to the region. This protest was considered by the soldiers as a threat to peace and 300 protesters were killed. Kaima town was invaded, several innocent citizens were murdered, under-aged girls and women raped at gun point (Alao, 2010). The destruction of Odi town on account of the murder of twelve police men is another instance of high-handedness in handling socioeconomic problems while the kidnapping and killing of security personnel the paper argues is barbaric.

Ken Saro-Wiwa chiefly sought to bring to the local and international community, the suffering and deprivation of the people of the Niger Delta, the Ogonis in particular whom he sought to mobilize using peaceful, non-violent means similar to the tactics of Mahatma Ghandi of India, Nelson Mandela of South Africa 
and Martin Luther King (Jr.) of America. He articulated the grievance in the Ogoni Bill of Rights drafted by the Movement for the Survival of the Ogoni People (MOSOP). Rather than address the demands outlined in the Ogoni Bill of Rights, the military regime under its tyrannical leadership of General Sani Abacha in November 1995 chose to conduct a jungle trial that led to the hanging of Saro-Wiwa, and eight others. Part of the resultant effect was the suspension of Nigeria from the Commonwealth of Nations while attracting several other sanctions by the international community (Osaghae, 2011; 1995; Suberu, 2008; Ikelegbe, 2001; Saro-Wiwa, 1995).

Years after the hanging of the minority rights activist and environmentalist, conditions in the oilfields remained appalling. This, coupled with the memory of the struggles of Isaac Boro in the 1960s, raised to a new level of intensity with the activities of ethnic minority resistance movements (Watts 2004; Sesay, 2003). Since the late 1990s however, there has been a very substantial escalation of violence across the delta oil fields. A variety of militia groups consequently got equipped with small and light weapons to fight the Government forces and the Multinational corporations (MNCs). They engaged in the disruption and destruction of oil installations, and vowed to crash oil production to a zero level if their grievances were adequately addressed with a view of collecting compensation from the Federal Government and Multinational oil companies for their losses (Ibeanu \& Momoh, 2008; Owugah, 2010; Ojakorotu \& Gilbert, 2010; Asuni, 2009).

To demonstrate the extent of despoliation, with respect to oil spillage, in year 2005, Shell alone accounted for 244 spills which in concrete terms, consisted of about 11,921 barrels, though issues of human error, corrosion and equipment failure accounted for $38 \%, 62 \%$ of incidents were caused by sabotage within the region through militant activities and bunkering (Shell Report, 2006). The same report also admits that gas flaring from oil production emits some 12 million tons of methane a year, making it the world's largest single contributor to global warming. Consequently, $85 \%$ of drinking water got polluted by sewage, and water-related diseases accounted for four-fifths of all illnesses. The flare as also reported in Alao (2010) polluted rain water and caused acid rain that also contributed to climatic change. The oil spillage destroyed significant proportion of areas used for fishing and other farm lands paralyzing the economic base of the region.

This led Aina (1991) to observe that:

In developed and developing countries the inability of man to develop the petroleum industry in an environmentally sustainable manner has resulted in severe environmental degradation and devastating ecological damage of different magnitudes due to multifarious causes from Alaska in USA, to North sea in France, Morocco to Nigeria and to Arabian gulf.

The above observation was corroborated by the people of Ogbugba in Edo State that:

Our joys have become sorrows because the oil production activities have completely destroyed the ecological systems of our clan. Aquatic life is almost completely destroyed, the soil completely eroded and flora and fauna badly affected almost to the level of extinction. In addition, oil exploration and production activities have subjected us to devastating erosion and permanent pollution, forcing us against our will to lie permanently in a toxic atmosphere.

The uprising by the oil-producing minorities however forced the Federal Government to accede to some of the demands of the people by allocating $3 \%$ of the federation account to tackle the ecological and other problems in the oil producing communities (Osaghae, 2011). The worrisome situation is that the oil bearing Niger Delta communities have basically remained grossly socio-economically dependent on crumbs from the Federal government and therefore underdeveloped, persistently disempowered, marginalized and psychologically alienated (Eteng, 1998). On the other hand, while the federal government is accused of not doing enough, it can be argued that the resources at the disposal of the State and Local government were not efficiently or judiciously deployed to improve the lives of the citizenry. The MNCs could not but seize the loophole of inefficient government to further despoil the region.

\section{The Pre-Amnesty Struggle}

On account of the government failure to address the problems facing the people of Niger Delta Region, there emerged many armed ethnic groups in the Niger Delta. The most prominent and politically relevant groups in terms sustained agitation and violent engagement against the government were the Federated Niger Delta Ijaw Communities (FNDIC); Niger Delta People's Volunteer Force (NDPVF); Niger Delta Strike Force (NDSF); Niger Delta Vigilantes Services (NDVS); People's Liberation Force (PLF); Movement for the Emancipation of the Niger Delta (MEND); Coalition for Militant Actions in the Niger Delta (COMA); Joint Revolutionary Council (JRC); and Martyrs Brigade (MB).

The strategies adopted by the militias groups were diverse including attacks on military locations, hostage taking for ransom, kidnapping, illegal oil bunkering, pipeline vandalization, sabotage, bombings, attacks on oil pipelines and installations, piracy, hijacking, armed robbery and political thuggery (Aaron \& George, 2010; JTF, 2007). This was the case because the groups were not coordinated with central command structure. 
This explains why a militant leader in an interview with International Crisis Group, (2006) said that some of the most senior leaders have remained wary of uniting too closely and that "we would have been destroyed by now if we are united, our strength is in our disunity". This encouraged the growth of small groups operating in "cells' beyond the control of major group leaders and largely without their knowledge. This explains why Osaghae, Ikelegbe, Olarinmoye, and Okhomina (2011), Nwajiaku-Dahou (2010), the Nordic African Institute (2009), Ibeanu \& Momoh (2008), Fisher-Thompson (2007) among others noted that the list of the armed ethnic formations could be endless. The implication therefore is that it was practically difficult to track many insurgencies and various group claimed responsibilities for many acts in order to gain prominence.

As reported in Campbell (2010), there were more than twenty militant groups in Bayelsa State alone. Each one had numerous smaller groups called 'cults' that was overseen by a 'master' to whom members owed their allegiance. Similar to Asari-Dokubo's assertion that there were over 312 separate Ijaw warlords in the entire Niger Delta region, each one with its own band and dedicated to bringing the Nigerian State 'to its knees' noted Abati, (2007). The groups were 'nebulous and difficult to categorize' as observed by Ikelegbe, (2010), Asuni, (2009) and JTF (2007). Many of the groups including those listed above are believed to be still cohesive even in the post-Amnesty period and now organize Amnesty stipend payments to their members. They still engage in economic activities such as government or industry contracting or illicit bunkering. A number of the militant leaders have become influential in politics and/or actively engaged in the running of the Amnesty Programme noted by Francis, LaPin \& Rossiaco, (2011). At the height of the insurgency (2006-2009), several persons worked on full or part-time with the various armed groups here discussed above and others listed elsewhere and earned a salary range of N10,000-N40,000 (\$85-\$340) per month, lower than the 2009-2015 amnesty stipend for ex-combatants of N65,000 (\$410) (Francis, LaPin \& Rossiaco 2011; Asuni, 2009).

The organizational structure adopted by the militant groups has the attributes of regular military forces, most especially unity of command, division of work (specialization), coordination, discipline, and esprit de corps. Their nature of operations required a dispersed, rather than concentrated force structure as earlier observed. Above all, each militia formation had only one leader or "military commander". Many of the leaders, or "military commanders" added some nick-names or appellations (a.k.a) to their names or titles. Thus, Chief Government Ekpemukpolo who jointly with Henry Okah (now serving a jail term in faraway South Africa) headed several of the camps, came to be referred to as "Tompolo"; Victor Ben Ebikabowei leader of a formation in charge of militia camps in southern Bayelsa, as "Boyloaf"; Solomon Ndigbara, in charge of a militia camp at Bori, Rivers State, as "Osama Bin Laden" (Osah, 2014).

The major groups that made more impact in hostage taking, political thuggery, and extortion of money from multinational oil companies as well as adjoining States in the Niger Delta maintained big camps which were fairly well organized and equipped. Minor camps were usually splinter groups from major camps and were encouraged to greater acts of criminality by the successes of the larger camps. Each of the major camps had strength up to 2,000 men while the minor camps had less than 100 men each. Every major camp could boast of several weapons including AK 47 rifles, GRMG, BNG, and RPG 7, Speed boats, Gun boats and Anti-aircrafts equipment (Osaghae, Ikelegbe, Olarinmoye, Okhomina, 2011; JTF, 2007). By 2009 Amnesty and unconditional pardon was declared for those who participated directly or indirectly in militancy in the region.

In addition, there was a political dimension to the crisis as governments and many political leaders in the region were alleged to have engaged the services of militant groups. The International Crisis Group Interview (2006) believes that the 2003 election provided the much needed fund and ammunitions for many militant groups as both the leaders of Peoples Democratic Party (PDP) and All Nigeria Peoples Party (ANPP) engaged their services as thugs. For instance, it was reported that Ateke, the leader of Niger Delta Vigilante group claimed that Governor Amaechi of Rivers State contributed a sum of fifty million Naira to his group to procure arms for 2007 electioneering campaign of the ruling party while Elendu (2005) corroborated the Ateke's statement above.

Though this allegation was denied by the Governor, this paper argues that instances of this nature abound and cannot be treated as figment of imagination. Such arrangements did not only provide ammunition for the militants but at the same time led to the creation of multiple factions of the group and sometimes competed among themselves for supremacy in order to attract the attention of the politicians. In effect, the stronger the boys were, the more the likelihood that they would be used by politician in Rivers State where elections were particularly bloody Alao (2010) observes.

In order to break the rank of the militants, the government and MNCs engaged in settlement syndrome as it backfired and constituted a setback in achieving the much desired peace. This was done instead of facing the developmental challenges of the region squarely. The International Crisis Group, (2006) reported that a selected few militant leaders were lucratively rewarded. In 2004, several key Ijaw and Itsekiri militants were appointed to State and Local government positions. Also in 2006, President Obasnjo's government reserved an oil block drilling license for a company linked to members of the Federated Niger Delta Ijaw Communities (FNDIC). This group actively coordinated and led Ijaw fighters during deadly conflicts in 1997, 1999, and 2003. 
According to the report, Shell also admitted giving Service Contract to FNDIC. The observable last record of such incident was reported "Delta Youth Leaders in Row over Contract" (The Nation, 2008). Funding the militants under any guise would empower them to be more diabolic and destructive in their activities. This also encourages the growth of subsidiary militant groups competing for the attention of higher bidder in their nefarious activities.

\section{Attempts At Tackling The Niger Delta Question}

A number of initiatives were embarked upon by the successive Governments in Nigeria directed at resolving Niger Delta conflict. Several commissions and committees were set up to look into the issue especially those bordering on under-development of the region and problems of militancy. Between 1958 and 2008, such commissions and committees included Commission Appointed to Enquire into the Fears of the Minorities and Means of Allaying them in 1958, the Justice Alfa Belgore Judicial Commission of Inquiry of 1992, the Ministerial Fact-Finding Team (the Don Etiebet Committee) of 1994, Major General Popoola Committee of 1998, and Lt. General Alexander Ogomudia Committee on the Special Security in Oil Producing Areas of 2001. Others include the 2003 Presidential Panel on National Security otherwise referred to as the Presidential Committee on Peace and Reconciliation, the Presidential Council on the Social and Economic Development of the Costal States of the Niger Delta, 2006 and the Technical Committee on the Niger Delta of 2008 among others.

Conservatively, over fourteen reports were submitted with all manner of recommendations as noted by TCND, (2008). Furthermore, the Federal Government established a host of interventionist agencies particularly directed at providing basic infrastructural amenities, social services and economic empowerment programmes in the Niger Delta. The agencies included: Niger Delta Development Board (NDDB), Niger Delta Basin Development Authority (NDBDA), the Oil Minerals Producing Areas Development Commission (OMPADEC), Niger Delta Development Commission (NDDC) and the Ministry of Niger Delta Affairs (MNDA)

In 2004 President Olusegun Obasanjo initiatiated 'cash for arms' amnesty for rival armed groups in Rivers State which involved Asari-Dokubo's Niger Delta People's Volunteer Force and Tom Ateke's Niger Delta Vigilantes and their affiliate groups. This initiative failed after six months of its commencement though over 3,000 weapons were recovered as the basic concerns in the region were not addressed and coupled with the poor implementation of the programme (Agbede, 2010; Davis, 2009 and Elendu, 2005).

The Technical Committee of the Niger Delta (TCND) recommended the creation of conditions for credible amnesty and establishment of a decommissioning, disarmament and reintegration commission. Consequently, on May 5, 2009 the Presidential Panel on Amnesty and Disarmament of Militants in the Niger Delta was set up to engage major stakeholders in the Niger Delta question in dialogue in the emerging peace process (Aaron \& George, 2010; Ikelegbe, 2010).

Upon the declaration of the Amnesty Programme as a peacebuilding initative in June 25, 2009, the Amnesty offer lasted for sixty (60) days, (August 6, 2009 to October 4, 2009) for the disarmament component, to allow demobilization and reintegration components to run till 2015. A total of 20,192 militants registered for the programme initially surrendering huge quantity of arms and ammunitions to the Federal Government's security agencies. Additional 6,166 former combatants benefited from the reintegration Programme in November 2010 under President Goodluck Jonathan as observed by Oluwaniyi, (2011). Another 3,642 youths were also added in October 2012 as the final figure stood at 30,000 as against 8,000-10,000 militants projected by the government (Akpan, 2010).

The reintegration of the ex-militants began with the initial monthly allowances of N20,000 and later pegged at N65,000.00. This was followed by giving of educational and vocational training in various skills acquisition programmes both at home and abroad while to get the trained ex-militants engaged became a serious challenge in the face of teeming unemployment (Ikelegbe, 2010).

The government under the leadership of President Goodluck Jonathan embarked on several projects in different communities of the Niger Delta region with N23 billion as part of the post-amnesty intervention programme meant to facilitate the rapid economic development of the region. According to the Ijaw News, (July 2011) some of the projects awarded include: the three land reclamation and erosion control/shoreline projects worth N5.8 million at Essien Town, Ekorinin community, Calabar, Amadi-Ama Road, Port Harcourt and Ogbobagbene, Burutu Local Government Area, Delta State. In addition there was the dualisation of the $99 \mathrm{~km}$ East-West Road, Section 111, Port-Harcourt/Eleme Junction, in Rivers and Eket in Akwa Ibom States; furthermore, the augmentation of the 50km dualisation East-West Road, Section IV (Eket-Oron Road) in Akwa Ibom State; the construction of Emakalakala-Akipelai Road and bridges in Bayelsa State and the construction of Gelegele Road in Edo State at the cost of N224.9 million.

President Yar'Adua allocated a sum of N52.85 billion the construction East-West road, coastal road and rail line, inland water transportation, reclamation to link all oil producing communities and environmental clean-up. In addition, in 2010, Delta State government spent US\$2.2 billion for reconstruction of Gbaramatu 
kingdom, an area destroyed when fighting ensured between the government security agencies and MEND. Bayelsa State claimed to have expended S $\$ 1.28$ billion for rebuilding access roads in the creeks, youth centres and health centres (Amula, 2009).

The reintegration and reconstruction programme is ongoing, though it could be seen as a pragmatic step to addressing the challenges of the region when placed side by side with past efforts; the next section will therefore examine the potentials for sustainable peace.

\section{Potentials For Peace Sustainability}

The paper argues that peace sustainability rests on achieving social and economic development that the citizenry will see as such rather than statements of intention by governments. There is no doubt that the amnesty programme implemented since 2009 is the first pragmatic step towards addressing the crisis in the Niger Delta Region. Unlike the previous efforts that could be regarded as cosmetic, the Yar Adua initiative was relatively inclusive rather than settlement syndrome of the past though the community members were not actively involved. It could be seen as the first attempt to recognize the problems beyond selfish objective of allowing crude oil to flow. The challenges were not only recognized but positive steps were taken to address them. This in no small way accounted for the relative peace in the region and increased revenue from the crude oil.

The study argues that sustainable peace in a region that had gone through protracted crisis and at the same time deep rooted and embraced by the entire member of the society required sustained investment in the peace process by speedily responding to the yearning of the citizenry. Also, it required continuity and progressive demonstration of sincerity of purpose by government and other stakeholders. In addition, the deplorable state of infrastructural development must be given adequate attention while the people in the region must see peace as not negotiable.

It has however been observed that the Amnesty Programme has been too much tied to the personalities of particular top political figures in government as well as some of the key ex-militant leaders from its inception without community involvement. This to a large extent can lead to politicization of the programme even if that is not the objective of the government. Anchoring the program on key militant leaders with no clearly established institutions might lead to exclusion of some individual who could foment trouble in future. The present disposition of the political leaders is subject to change particularly in an unstable political system like Nigeria. Therefore, there is need for reconsideration of the present implementation of the amnesty programme

In addition, large quantity of unreported arms is still circulating in the region as not all militant groups supported the deal. This in part, may have accounted for the continuing low level violence like armed robbery, banditry and kidnapping in the post-Amnesty era. This is a true reflection of societies just emerging from armed conflict as rightly observed by Adekanye (1996); Berdal (1996), Kingma (1996) and Sisk (2001). To date, there are still no clear and concerted efforts as well as creative strategies for mopping up arms in the Niger Delta region after the general disarmament exercises that ended on October 4, 2009.

Since the commencement of the amnesty programme, as rightly observed in the preceding section, the achievement recorded in infrastructural development is not commensurate with physical and psycho-social damage of the crisis and the neglect by the previous governments. Moreover, the implementing agencies for executing the programmes for social and economic reconstruction were not under the Amnesty Office, but lay elsewhere. Besides, two of the key agencies namely Niger Delta Development Commission (NDDC) and Ministry of Niger Delta Affairs (MNDA) were found not to perform optimally due to bureaucratic challenges, underfunding and corruption (Osah, 2014). The paper argues that peace sustainability rests on achieving social and economic development that the citizenry will see as such rather than statements of intention by governments.

The Amnesty as it stands is erroneously perceived as an end rather than a means to an end. The postAmnesty packages should not to be limited to militants alone. Concrete and detailed post amnesty programme is equally not yet produced and communicated to the people in the region as a means of getting then prepared for the future. For instance the President Yar'Adua's N179.13 billion initiative for 44 projects by NDDC in the nine States of the region to accommodate construction of roads and bridges, drainages, hospitals and the purchase of hospital equipment, provision of portage water, educational facilities and environmental impact assessment programmes are suppose to provide a platform for development rather than the wrong perception by the people that the flow of free resources will never run dry.

It is of importance to acknowledge that for prevailing relative peace to be sustained, the war economy is one problem area that has not been seriously considered. The crisis in the region was sustained because of those who were feeding fat from the crisis in terms of vandalization of pipe lines, crude oil theft, raids on communities and other form of crime that were financially rewarding including those who claimed to be negotiating peace. Without due consideration of this fact, and the seizure of unearned income might encourage such group to clandestinely foment trouble (Osah, 2014). 
Furthermore, the systematic neglect of non-militant elements of various communities in the Niger Delta is a serious error. The implication is that those neglected might constitute a $\operatorname{cog}$ in the wheel of progressive sustainable peace as it is an invitation to regroup and foment trouble so as to be recognized by the government. Failure to achieve this may wipe off the relative peace induced by the Amnesty Programme within the next five years.

Stemming from above, as rightly observed by Darby \& Mac Guinty, (2003), Sisk, (2001) Adekanye, (1996), and Kingma, (1996) 'war-to-peace' transition research projects, has been found that 'demobilization' has not been accompanied by 'effective disarmament'. This may explain why some militant groups refused to key into the amnesty programme and even such exercise during Obasanjo regime failed to achieve the expected result as most of the key militant leaders claimed that unserviceable gun were surrendered. To overcome this challenge, the study argues that strategies like 'cash for guns', institution of peace and stability committees at community levels to take charge of ownership, control and use of weapons, provided that government objectives for the action will not be compromised by their leaders. This is expected to go a long way in dealing with the suspected large quantity of unreported arms diffused and circulating within the region. These illegally stocked "surplus" weapons poses continuing security threats in any post-conflict society.

Available evidences point in the direction that some of the trained ex-combatants are yet to be economically reintegrated or gainfully employed. It has been found that most of those trained locally and in various institutions abroad are yet to be gainfully employed either by direct employment by the stakeholders or financial support to set up businesses for them. Idle hands are the best weapon in the hand of the devil to foment trouble and this is to be given deserving attention if the fragile peace is to be sustained.

In addition, there is need for synergy between the key agencies of Government at all levels: federal, state and local implicated in the challenge of the Niger Delta, to coordinate their activities and work in harmony with the view of delivering peace dividends to the people of the Niger Delta. Holistic implementation of the 2010 United Nations Environmental Programme (UNEP) report is required. The multinational oil companies have a crucial role to play here, and must rise up to their corporate social responsibility as regards the environmental pollution problem. This collaborative effort still must be improved upon to achieve sustainable peace.

\section{Conclusion And Recommendations}

The amnesty programme, no doubt has been a positive step to restore peace to the trouble Niger Delta region regardless of the observable challenges. The paper concludes that the attainment of sustainable peace is not unattainable as there was demonstrated sincerity by the current government greater than those of preamnesty era. Also, sustainable peace could not be possible if the government perceive the need for peace solely as a mean of ensuring uninterrupted extraction of crude oil. The challenges are not insurmountable given the sincerity of purpose by the government and the willingness of other stake holders including all the communities in the region to see sustainable peace as non-negotiable. However, judging by the present modest achievement, the study argues that sustainable peace cannot be achieved without continuous reevaluation of the programme and projecting into the future rather focusing largely on ex-militant alone.

The study recommends that sustainable peace rests on the joint support of both combatants and the communities in the entire region rather than only on militants who have been the focus of the amnesty programme. There is therefore the need for the whole communities to own the peace process rather than selected political leaders and the ex-militants. The study further recommends that instead of anchoring the programme on personalities, building institution that can sustain the programme is desirable as all the stakeholders are suppose to 'own' the peace.

It is further recommended that all the stakeholders be it the federal and state governments as well as the oil companies among others must see it as their responsibilities to engage the ex-militants that were trained to minimize future havocs. Instead of placing them of monthly stipend, getting them established in one business or another should be the priority of government.

The government must see disarmament as a continuous programme as all evidences pointed in the direction that large stock of arms are in circulation as this is a challenge to sustainable peace. The mop-up exercise and demilitarization of the Niger Delta region should therefore be another priority on the Federal Government's policy agenda.

\section{Biographical References}

[1]. Aaron, K.K. \& George D. (2010). Placebo as Medicine: The Poverty of DevelopmentIntervention and Conflict Resolution Strategies in the Niger Delta Region of Nigeria. Port Harcourt: Kemuela Publications

[2]. Abati, R (2007). 'Warlords of the Niger Delta.' The Guardian (Lagos) October 4

[3]. Adekanye, J. 'B. (1996). 'Disarming Ethnic Guerrillas, Power-sharing and Transition toDemocracy in Africa' (A Toyota funded Projects) Final Research Report. International Peace Research Institute, Oslo, PRIO

[4]. Agbede, A.R.S. (2010). Nigeria and the Challenges of Effective Security. Ibadan: Netview Books

[5]. Aina, E. (1991). Text of Press Briefing Marking World Environmental day. (Unpublished): Lagos 
[6]. Akinwale A. A. (2010) 'Amnesty and Human Capital Development Agenda for the Niger Delta'in Journal of African Studies and Development vol. 2 (8)

[7]. Ako, R. (2011). The Struggle for Resource Control and Violence in the Niger Delta. Oil and Insurgency in the Niger Delta: Managing the complex politics of petro-violence. London/New York: Zed Books, 70-81.

[8]. Akpabio, E.M. \& Akpan, N. S (2010). Governance and Oil Politics in Nigeria's Niger Delta: TheQuestion of Distributive Equity. Journal of Human Ecology 30 (2). Pp 111-121

[9]. Alao, D.O (2010). "Towards an Enduring Peace in the Niger-Delta Region: An AnalyticalStudy". Babcock Journal of History and international Studies, 2010/2011.

[10]. Anifowose, R. (2011). Violence and Politics in Nigeria: the Tiv, Yoruba and Niger Delta Experience.Lagos: Sam Iroanusi Publishers

[11]. Asuni, J. B. (2009). 'Understanding the Armed Groups of the Niger Delta'. Council on Foreign Relations. Working paper

[12]. Azaiki, S. (2007). Oil, Gas and Life in Nigeria. Ibadan: Y-Books

[13]. Bawer, B.(2007). "The Peace Racket". City Journal, Summer. Retrieved fromhttp://www.city journal.org/html/17 3 peace racket $\mathrm{html}$.

[14]. Berdal, M. R. (1996). Disarmament and Demobilisation after Civil Wars. Adelphi Paper 303,International Institute for Strategic Studies (IISS): Oxford University Press

[15]. Boahen A. (1981). Topics in West African History. Burnt Mill: Harlow, Communication Ltd

[16]. Boro, I. A. (1982). The Twelve Days Resolution. Benin City: Idode Umeh Publishers

[17]. Boulding, K.E (1977). "Twelve Friendly Quarrel with Johan Galtung”. Journal of Peace

[18]. Research Vol.14. No.1 pp 75-86 retrieved from http;//www.Jsttor.org/pss/423312. Accessed

[19]. Sept. 21, 2011.

[20]. Darby, J. \& R. Mac Guinty (2003). Contemporary Peacemaking: Conflict, Violence and PeaceProcess. New York: Palgrave Macmillan

[21]. Davis, S. (2009). The Opportunity for Peace in the Niger Delta. Global Energy andEnvironment Initiative Green Paper Series, No 2

[22]. Doyle, M. and Sambanis, N. (2007). "Building Peace: Challenges and Strategies After Civil War," The United States World Bank Group. Retrieved from http://www/worldbank.org/research/conflict/papers/building.pdf)3

Easton, D. (1979). A Framework of Political Analysis. Chicago and London: The University of Chicago Press

[23]. Elendu, J. "They Paid for our Guns" Asari Dokubo: Elende Reports, in http//elendureports.com accessed Nov. $14,2005$.

[24]. Fisher-Thompson, J. 2007. 'U.S. Partners with Nigeria on Security for Oil-Rich Delta Region.' USINFO, US Department of State. 15 March.

[25]. Francis, P., LaPin D., \& Rossiaco P, (2011) Securing Development and Peace in the Niger Delta: A Social and Conflict Analysis for Change. Woodrow Wilson International Center for Scholars

[26]. Fubara, B. A (2002) 'The Politics of the Niger Delta' in Ozon-Eson, P. I \& Ukiwo. U (eds.) The Niger Delta Development Commission: Towards a Development Blueprint. Port Harcourt: Centre for Advanced Social Science (CASS)

[27]. Dollard, J., Dobb, L.W., Miller, N.E., Mower, O.H., and Seers, R.R. (1939) Frustration and Aggression. New Haven: Yale University Freer, 1939.

[28]. Ibaba, S.I. (2011). Terrorism in Liberation Struggles: Interrogating the Engagement Tactics ofNthe Movement for the Emancipation of the Niger Delta" Perspectives on Terrorism, Vol. 5, No. 3\&4 pp 18-32

[29]. Ibeanu, O. \& Momoh, A. (2008). 'State Responsiveness to Public Security Needs: The Politics of Security Decision Making' in Conflict, Security and development Group No 14

[30]. Ikelegbe, A. (2001) Civil Society, Oil and Conflict in the Niger Delta Region of Nigeria: Ramification of Civil Society for a Regional Resource Struggle Journal of Modern African Studies, 39, (3) $437 \quad 469$

[31]. Ikelegbe, A. (2004). Crisis of Resistance: Youth Militias, Crime and Violence in the Niger Delta Region of Nigeria. African Studies Centre Seminar

[32]. Ikelegbe, A. (2005) 'The Economy of Conflict in the Oil Rich Niger Delta Region of Nigeria' Nordic Journal of African Studies 14(2)pp. 208-234

[33]. Ikelegbe, A. (2010). Oil, Resource Conflicts and the Post Conflict Transition in the Niger Delta Region: Beyond the Amnesty. Centre for Population and Environmental Development (CPED)

[34]. Imobighe, T. A. (2004) Conflict in Niger Delta: A Unique case or a Model for Future Conflicts in Other Oil Producing Countries in Rudolf Traub- Mern and Douglas Yates (eds) Oil Policy in the Gulf of Guinea: Security and Conflict, Economic Growth, SocialDevelopment Bann: Friedrich Elbert Stifting.

[35]. International Crisis Group (2006), African Report: September 28, No 118

[36]. International Crisis Group Interview, Port-Harcourt, Environmental Day, Lagos, (April, 2006.)

[37]. Isoun T. T. (2001). 'Environmental Challenges of the Niger Delta' in Ozon-Eson, P.I. \& Ukiwo U. (eds.) Challenges of the Niger Delta: Port Harcourt: Centre for Advanced Social Science (CASS)

[38]. Joint Task Force (2007). 'Strategies to Stem out Militant Activities within the Joint Task Force Area of Responsibility' Secret Report

[39]. Kay, B. (2009)."Barbarians within the Gate", National Post, February $18 . \quad$ Retrieved from http://www.barbarakay.ca/index.php?option=com_content\&view article.id+20. Accessed on September 21, 2011.

[40]. Kingma, K (1996). 'The Role of Demobilization in the Peace and Development Process in SubSaharan Africa: Conditions for Success' African Security Review Vol. 5 No 6 pp 33-42

[41]. Morris , C., Hoffman, B., Peachey, E. (2009).” In defence of peace studies" NationalPost, February 25,

[42]. Niger Delta Development Commission Act (2000).

[43]. Nna-Ntete, J. (2001). The Niger Delta: State Legislations and Disempowerment. Owerri. SpringfieldPublications

[44]. Nwachukwu, J. N. (2008). 'The Niger Delta Imbroglio: An Agitational Terrorism or a Strategic Confronattion' in Babcock Journal of Management and Social Sciences vol. 6. No2

[45]. Nwajiaku-Dahou, K (2010). The Politics of Amnesty in the Niger Delta: Challenges Ahead. Paris and Brussels: The Institut français des relations internationales (IFRI).

[46]. Obi, C.I (2000). Oil Minority Rights and the Question of Democratic Stability in Nigeria', Journal of Cultural Studies, Vol. 2, No. $1,2000$.

[47]. Ogbugba Community, Paper Presented to the Ministerial Committee on Communal Conflict

[48]. Ojakorotu, V. \& Gilbert, L. D. (eds.) (2010). Checkmaking the resurgence of Oil Violence in the Niger Delta of Nigeria.

[49]. Okai, M. O. (2008). Religion and Social Conflict Management: The Case of the Niger Delta Region of Nigeria. Port Harcourt: Cal Integrated Resources 
[50]. Okai, M. O. (2008). Religion and Social Conflict Management: The Case of the Niger Delta Region of Nigeria. Port Harcourt: Cal Integrated Resources

[51]. Oku, H. B. (2003). The Niger Delta Environment: Its Local Geography. Port- Harcourt: Prelyn Publishers

[52]. Osaghae, E. E (1995). The Ogoni Uprising. African Affairs 94:325-344.

[53]. Osaghae, E. E. (2008). Social Movements and Rights Claims: The Case of Action Groups in the Niger Delta of Nigeria. Voluntas, 19, 189-210. http://dx.doi.org/10.1007/s11266-008 9061-0

[54]. Osaghae, E. E. (2011). The Crippled Giant: Nigeria Since Independence. Ibadan: John Archers Publishers

[55]. Osaghae, E. E., Ikelegbe, A, Olarinmoye, O. O. \& Okhomina, S.I. (2011) 'Youths Militias, Self Determination and Resource Control Struggles in the Niger Delta Region of Nigeria'. Dakar, CODESRIA, Research Report n ${ }^{\circ} 5.1$

[56]. Osah, G. (2014) Disarming Ethnic Militants and Post-conflict Peacebuilding in the Niger Delta, Nigeria. Babcock University, Ilishan-Remo, Nigeria. Unpublished $\mathrm{PhD}$ Thesis

[57]. Owugah, L. (2010). 'State's Violent response Strategy to the Niger Delta Conflcit: Resolution or Containment' in Aaron, K.K. \& George D. Placebo as Medicine: The Poverty of Development Intervention and Conflict Resolution Strategies in the Niger Delta region of Nigeria. Port Harcourt: Kemuela Publications

[58]. Saro-Wiwa, K. B. (1995). A Month and a Day: A Detention Diary. New York, N.Y.: Penguin Books.

[59]. Sesay, A; Ukeje C; Aina, O; Odebiyi, A. (eds) (2003). Ethnic Militias and the future of Democracy in Nigeria. Ile-Ife: Centre for Development and Conflict Management Studies.

[60]. Shell Nigerian Annual Report, 2006 in http:// www. Shell.com

[61]. Sisk, T. (2001). 'Peacemaking in Civil wars: Obstacles, Options, and Opportunities'. Occassional Paper No 20 of the Joan B. Kroc Institute for International Peace Studies, University of Nortre Dame

[62]. Sogwe, C.M. (1997). A Textbook of Niger Delta History. Ibadan: Rescue Publication

[63]. Suberu, R.T. (2008). 'The Supreme Court and federalism in Nigeria,' Journal of Modern African Studies 46(3):451-85.

[64]. Tamuno, T.N. (1972). The Evolution of Nigerian State Longman: London

[65]. The Nordic African Institute (2009)

[66]. Watts, M. (2004) 'Resource Curse? Governmentability, Oil and Power in the Niger Delta', Nigeria Geopolitics, 9 (1), 50-80

[67]. Willink Commission Report (1958). 'Report of the Commission Appointed to Enquire into the Fears of the Minorities and the Means of Allaying' London: Her Majesty's Stationary

Office and accessed at http://www.adakaboro.org 